\title{
Biodegradation of hydrocarbon mixtures in surface waters at environmentally relevant levels - Effect of inoculum origin on kinetics and sequence of degradation
}

Birch, Heidi; Hammershøj, Rikke Høst; Comber, Mike; Mayer, Philipp

Published in:

Chemosphere

Link to article, DOI:

10.1016/j.chemosphere.2017.05.169

Publication date:

2017

Document Version

Peer reviewed version

Link back to DTU Orbit

Citation (APA):

Birch, H., Hammershøj, R. H., Comber, M., \& Mayer, P. (2017). Biodegradation of hydrocarbon mixtures in surface waters at environmentally relevant levels - Effect of inoculum origin on kinetics and sequence of degradation. Chemosphere, 184, 400-407. https://doi.org/10.1016/j.chemosphere.2017.05.169

\section{General rights}

Copyright and moral rights for the publications made accessible in the public portal are retained by the authors and/or other copyright owners and it is a condition of accessing publications that users recognise and abide by the legal requirements associated with these rights.

- Users may download and print one copy of any publication from the public portal for the purpose of private study or research.

- You may not further distribute the material or use it for any profit-making activity or commercial gain

- You may freely distribute the URL identifying the publication in the public portal 
1 Biodegradation of hydrocarbon mixtures in

2 surface waters at environmentally relevant

${ }^{a}$ Technical University of Denmark, Department of Environmental Engineering, Building 115, 2800 Kgs.

\section{Abstract}

Biodegradation is a dominant removal process for many organic pollutants, and biodegradation tests serve as tools for assessing their environmental fate within regulatory risk assessment. In simulation tests, the inoculum is not standardized, varying in microbial quantity and quality, thereby potentially impacting the observed biodegradation kinetics. In this study we investigated the effect of inoculum origin on the biodegradation kinetics of hydrocarbons for five inocula from surface waters varying in urbanization and thus expected pre-exposure to petroleum hydrocarbons. A new biodegradation 
method for testing mixtures of hydrophobic chemicals at trace concentrations was demonstrated:

17 Aqueous solutions containing 9 hydrocarbons were generated by passive dosing and diluted with surface

18 water resulting in test systems containing native microorganisms exposed to test substances at $\mathrm{ng}-\mu \mathrm{g} / \mathrm{L}$

19 levels. Automated Headspace Solid Phase Microextraction coupled to GC-MS was applied directly to

20 these test systems to determine substrate depletion relative to abiotic controls. Lag phases were

21 generally less than 8 days. First order rate constants were within one order of magnitude for each

22 hydrocarbon in four of the five waters but lower in water from a rural lake. The sequence of degradation

23 between the 9 hydrocarbons showed similar patterns in the five waters indicating the potential for using

24 selected hydrocarbons for benchmarking between biodegradation tests. Degradation half-times were

25 shorter than or within one order of magnitude of BioHCwin predictions for 8 of 9 hydrocarbons. These

26 results showed that location choice is important for biodegradation kinetics and can provide a relevant

27 input to aquatic exposure and fate models.

\section{Keywords}

29 Biodegradation kinetics, volatile petroleum hydrocarbons, composed mixtures, SPME, Passive dosing

\section{$30 \quad$ 1. Introduction}

31 Biodegradation is a dominant removal process for many organic pollutants in the aquatic environment,

32 and quantitative knowledge and data on biodegradation kinetics are therefore needed in water research,

33 environmental risk assessment and aquatic fate models. Petroleum products are complex mixtures of

34 varying composition consisting of a large number of chemical structures and degraded by equally

35 complex microbial communities in the environment (Abbasian et al., 2015; Hazen et al., 2016; Head et

36 al., 2006; Van Hamme et al., 2003). Experimental biodegradation data are not available for most of the 
37 constituents of petroleum products. Therefore a biodegradation prediction model (BioHCwin) has been

38 developed (Howard et al., 2005) and shown to perform well for classifying persistence conservatively

39 (Prosser et al., 2016). However, there is a lack of high-quality experimental kinetic data useful for

40 optimization of this and other prediction models (Rücker and Kümmerer, 2012).

41 Suitable testing methods are important for generating high-quality experimental data at environmentally

42 realistic concentrations (Prince et al., 2017). Most of the constituents in petroleum products are

43 hydrophobic and have very low solubilities. Passive dosing from a silicone polymer has earlier been used

44 to improve and simplify test methods for hydrophobic organic chemicals in toxicity tests (Smith et al.,

452010 ) and distribution measurements (Birch et al., 2012) by producing stable concentrations of freely

46 dissolved chemicals and avoiding the use of solvents in the test systems. Passive dosing has also been

47 introduced for biodegradation tests of single chemicals (Smith et al., 2012) and mixtures (Comber et al.,

48 2012). In this study we designed and included a passive dosing method in biodegradation tests to

49 investigate mixtures composed of potential petroleum hydrocarbons at environmentally relevant

50 concentrations, 2-4 orders of magnitude below the solubility of the test chemicals.

51 Although the physical and chemical test conditions which can affect biodegradation (Leahy and Colwell,

52 1990) are largely standardized in tests such as the OECD test series (OECD 301, 1992; OECD 303, 2001;

53 OECD 306, 1992; OECD 309, 2004), the biological conditions of the inoculum is poorly defined and

54 variable with respect to cell density, species, origin and history of the sample (Kowalczyk et al., 2015;

55 Thouand et al., 2011). Pre-exposure to the tested chemical or similar chemical structures has been seen

56 to enhance degradation by adaptation of the microbial community (Bauer and Capone, 1988; Leahy and

57 Colwell, 1990; Marchal et al., 2003), and lag phases have been seen to depend on cell density in tests

58 (Caparello and Larock, 1975), pre-adaptation of inoculum (Toräng and Nyholm, 2005) and total amount 
59 of specifically degrading bacteria (Ingerslev et al., 2000). Previous studies reported the difference in

60 biodegraded percentages of gasoline, diesel oil, crude oil and kerosene in soil samples (Hamamura et al.,

61 2013; Marchal et al., 2003), hexadecane in surface water samples (Caparello and Larock, 1975), crude oil

62 constituents in sea water (Kristensen et al., 2015), diesel and lubricating oil in sediments (Powell et al.,

63 2007) and selected hydrocarbons in water-sediment mixtures from lakes (Cooney et al., 1985). A concept

64 has been proposed recently to target the environmental microbial variability from a probability

65 perspective in which 10 different inocula are used in ready biodegradability tests to evaluate the

66 probability of biodegradation in the environment (Thouand et al., 2011). However, the kinetics of the

67 biodegradation was not targeted in the above mentioned studies. Given that diverse microbial

68 communities of hydrocarbon degraders are generally present in the aquatic environment (Hazen et al.,

69 2016; Van Hamme et al., 2003), the lag phase, being the time during which the bacteria adjust to the

70 substrate and multiply, is potentially the main parameter influenced by pre-exposure of the inoculum.

71 Once degradation is initiated, the rates could therefore be similar and independent of the level of pre-

72 exposure of the sampling locations. The aim of this study was therefore to investigate the effect of the

73 inoculum origin on biodegradation kinetics. The surface water sampling locations were thus selected to

74 represent different degrees of pre-exposure to petroleum hydrocarbons. Pre-exposure to petroleum

75 hydrocarbons was assumed for locations receiving rainwater runoff discharges (Göbel et al., 2007).

76 Locations ranging from rural locations with no known point sources to urban locations receiving

77 rainwater runoff discharges were selected based on point source information from the Danish river basin

78 management plans (The Danish Nature Agency, 2011a, 2011b). We tested the degradation in natural

79 surface water samples without addition of sediment to ensure a high bioavailable fraction and corrected

80 for partitioning to headspace (Birch et al., 2017). 
81 For petroleum hydrocarbons, a general sequence of susceptibility towards biodegradation has been

82 reported as $n$-alkanes $>$ iso-alkanes $>$ low-molecular weight aromatics $>$ cyclic alkanes $>$ PAHs, although

83 exceptions are seen (Leahy and Colwell, 1990). This sequence has also been observed in the field, where

84 after oil spills, the abundance of specialist alkane degraders generally show a bloom followed by a bloom

85 of specialist aromatic hydrocarbon degraders (Head et al., 2006). A further aim of the study was

86 therefore to determine whether the sequence in which the hydrocarbons were degraded remained the

87 same across the sites. If this was the case, then the design would not only facilitate comparisons of

88 biodegradation results from different water sampling locations but also provide a new basis for

89 extrapolating biodegradation results.

90 The focus of this study was therefore to see whether (1) using water from locations with higher

91 urbanization would result in shorter lag phases in the biodegradation test compared to locations with

92 less urbanization, (2) biodegradation rate constants would be less affected than lag phases by the

93 sampling location and (3) the sequence of degradation of the hydrocarbons would be consistent across

94 different locations. Additionally, we compared the obtained biodegradation kinetic data from the

95 present study to BioHCwin predictions.

\section{2. Materials and methods}

\section{2.1. Materials}

98 Test chemicals included potential petroleum hydrocarbons with 8 to 12 carbon atoms: $n$-decane, 99 tetralin, biphenyl, trans-decalin, bicyclohexyl, 1,2,4-trimethylbenzene (tmbenzene) and naphthalene

100 (Sigma-Aldrich, Copenhagen, Denmark, purity $\geq 98 \%$ ), 2,3-dimethylheptane (dmheptane) and 1,3,5101 trimethylcyclohexane (tmcyclohexane) ( $\mathrm{TCl}$ chemicals, Zwijndrecht, Belgium, purity $\geq 98 \%$ ). 1-octanol 102 (Sigma-Aldrich, Copenhagen, Denmark, $\geq 99 \%$ ) was included as a reference chemical (positive reference 
103 for microbial activity in the test). Passive dosing systems were prepared using translucent silicone rods

104 (custom-made by Altec Products Ltd., Victoria, UK, product code 136-8380) in $100 \mathrm{~mL}$ amber Wheaton

105 glass serum bottles with crimp seals and PTFE-coated silicone septa. Ethyl acetate (Sigma-Aldrich,

106 Copenhagen, Denmark, $\geq 99.7 \%$ ) and ethanol (VWR chemicals, Søborg, Denmark, 99.8\%) were used for

107 cleaning of silicone rods. LaboStar ${ }^{\top M}$ 1-DI ultrapure water system from SGwater (Hamburg, Germany)

108 was used to produce ultrapure water.

\section{$110 \quad 2.2$ Generating stock solution by accelerated passive dosing}

111 Silicone rods were cleaned, loaded with test chemicals and equilibrated with ultrapure water to produce

112 a stable and reproducible low concentration stock solution for the biodegradation tests. The cleaning

113 procedure included washing three $20 \mathrm{~g}$ silicone rods (diameter: $3 \mathrm{~mm}$, approx. length: $2.6 \mathrm{~m}$ ) in a

114 dishwasher without the use of cleaning agents, soaking in ethyl acetate for 24 hours, soaking in ethanol

115 for 24 hours and heating to $120^{\circ} \mathrm{C}$ for 2 hours. Equal mass of the 9 test chemicals were mixed and the

116 two solid hydrocarbons readily dissolved in the liquid hydrocarbons. This mixture was added to the rods

117 (200 $\mu \mathrm{L}$ each) and was completely absorbed into the silicone by swelling (bottles were rolled horizontally

118 for $>24$ hours). Subsequently, each silicone rod was equilibrated with $65 \mathrm{~mL}$ of ultrapure water on a

119 roller at room temperature for 1 hour. Without knowing the exact partition ratio between silicone and

120 water for each chemical, adding an equal mass of chemical to the silicone results in water concentrations

121 that are roughly the same fraction of the solubility for each chemical. Equilibration times of $<10$ minutes

122 were confirmed for all test chemicals prior to the biodegradation tests. The resulting stock solution was

123 diluted 10 times when preparing test systems and test concentrations were later measured for three

124 abiotic controls to approximately $0.03 \mu \mathrm{g} / \mathrm{L}$ bicyclohexyl, $0.2 \mu \mathrm{g} / \mathrm{L} n$-decane and 2,3-dimethylheptane,

$1250.5 \mu \mathrm{g} / \mathrm{L}$ trans-decalin and 1,3,5-trimethylcyclohexane, $30 \mu \mathrm{g} / \mathrm{L}$ biphenyl and tetralin, $60 \mu \mathrm{g} / \mathrm{L}$ 1,2,4- 
126 trimethylbenzene and $70 \mu \mathrm{g} / \mathrm{L}$ naphthalene, which was 2-4 orders of magnitude below the water

127 solubility of each test chemical. Transfer of stock solution to test systems was done using gas tight

128 syringes (glass, PTFE). The loaded silicone rods were used multiple times without reloading and mass

129 balance calculations showed $<3 \%$ depletion of the silicone.

130

\section{$131 \quad 2.3$ Surface water inocula}

132 Five surface water grab samples, collected from three Danish streams and two Danish freshwater lakes, 133 were used as inocula (Supporting information S1). Samples were collected from the 12th to 21st October 1342015 and used within 24 hours after collection. A description of the locations can be seen in Table 1.

136 Temperature, $\mathrm{pH}$, dissolved oxygen and conductivity were measured immediately after sampling using 137 portable meters. Indicative levels of nitrate, ortho-phosphate and ammonium were measured with 138 manufactured test kits from Merck Millipore. Initial bacterial density was measured as heterotrophic 139 plate counts using a non-selective agar (Fluka ${ }^{\circledR}$ Analytical 17209 R-2A agar) within 24 hours of sampling.

$140 \mathrm{H}_{3} \mathrm{PO}_{4}$ was added to a subsample from each location (to conserve the sample at $\mathrm{pH} 2$ ) and nonvolatile 141 organic carbon (NVOC) was measured on a Shimadzu Total Organic Carbon Analyzer TOC-Vwp. 142 Background concentrations of test chemicals were below detection limits in all surface waters. 
Table 1: Surface water sampling locations

\begin{tabular}{lllll}
\hline Characteristics & Location name & Catchment & $\begin{array}{l}\text { Possible petroleum } \\
\text { hydrocarbon pre-exposure }\end{array}$ & $\begin{array}{l}\text { Ecological } \\
\text { status* }\end{array}$ \\
\hline Rural lake & Magles $\varnothing$ & $\begin{array}{l}\text { Woods, shrubbery } \\
\text { and field }\end{array}$ & No known point sources & High \\
Urban lake & Lyngby lake & $\begin{array}{l}\text { Urban and rural areas } \\
\text { through a tributary } \\
\text { stream }\end{array}$ & $\begin{array}{l}\text { Stormwater runoff from } \\
\text { paved areas and combined } \\
\text { sewer overflows }\end{array}$ & Bad \\
Rural stream & Fønstrup stream & Woods & No known point sources & High \\
\hline $\begin{array}{l}\text { WWTP** } \\
\text { impacted stream }\end{array}$ & $\begin{array}{l}\text { Gadevangs } \\
\text { stream }\end{array}$ & $\begin{array}{l}\text { WWTP** outlet, } \\
\text { Meadow and copse }\end{array}$ & $\begin{array}{l}\text { WWTP** outlet and } \\
\text { combined sewer overflow }\end{array}$ & Moderate \\
Urban stream & $\begin{array}{l}\text { Harrestrup } \\
\text { stream }\end{array}$ & Urban areas & $\begin{array}{l}\text { Stormwater runoff from } \\
\text { paved areas }\end{array}$ & Poor \\
\hline
\end{tabular}

*according to the criteria detailed in the European Water Framework Directive, Annex V, High = no or

146 only very minor anthropogenic alterations to the water body relative to those normally associated with

147 that type under undisturbed conditions, Good = low levels of anthropogenic alterations, Moderate =

148 moderate alterations, Poor = major alterations, $B a d=$ severe alterations $($ European Parliament, 2000), as

149 evaluated by The Danish Nature Agency (2011a, 2011b) **WWTP= wastewater treatment plant

\subsection{Biodegradation testing}

152 The biodegradation experiments were designed to measure biodegradation by substrate depletion in

153 test systems relative to abiotic controls. Each biodegradation experiment was therefore composed of a

154 series of test systems and an equal number of abiotic systems that were incubated in parallel. All

155 systems were prepared in $20 \mathrm{~mL}$ amber glass vials closed with screw caps and PTFE-coated silicone

156 septa. To prepare the test systems, $1.5 \mathrm{~mL}$ stock solution was diluted 10 times into surface water spiked

157 with $30 \mu \mathrm{g} / \mathrm{L}$ of 1-octanol. Abiotic systems were prepared with ultrapure water instead of surface water.

158 Blank controls were included. The test- and abiotic systems were incubated at $20{ }^{\circ} \mathrm{C}$ on a bench top

159 laboratory roller at $\approx 30 \mathrm{rpm}$. At different time points (e.g. day $0,1,2,3,4,5,7,10,14,21,28$ and 56) 
triplicate test systems, triplicate abiotic systems and a blank control were sacrificed for chemical 161 analysis.

$163 \quad 2.5$ Chemical analysis

164 Automated Headspace Solid Phase Micro Extraction (HS-SPME) (PAL RSI 85 auto sampler) coupled to Gas 165 Chromatography - Mass Spectrometry (GC-MS) (Agilent Technologies 7890B/5877A GC/MSD) was 166 applied to measure the 9 hydrocarbons. Rather than measuring on sub-samples of the test system, 167 automated HS-SPME was applied directly to test systems and abiotic controls to optimize the analytics, 168 minimize losses and minimize the risk for contaminations. HS-SPME sampling was done for 10 minutes at $16935{ }^{\circ} \mathrm{C}$ directly in the $20 \mathrm{~mL}$ test systems using a $100 \mu \mathrm{m}$ PDMS fiber (SUPELCO, Bellefonte) with shaking at $170250 \mathrm{rpm}$ alternating 5 seconds on and 2 seconds off. Desorption was performed at $250^{\circ} \mathrm{C}$ in the injection 171 port using a 2:1 split for 3 min followed by a 33:1 split for 2 minutes. Separation was done on a $30 \mathrm{~m}$ DB-

$1721 \mathrm{~ms}$ column of $0.25 \mathrm{~mm}$ inner diameter and $0.25 \mu \mathrm{m}$ film thickness using Helium as carrier gas at 1.2 $173 \mathrm{~mL} / \mathrm{min}$. Oven temperature was $35^{\circ} \mathrm{C}$ for 6 minutes followed by a ramp of $15{ }^{\circ} \mathrm{C} / \mathrm{min}$ to $300{ }^{\circ} \mathrm{C}$. The $\mathrm{GC}$ 174 signal was split between the MS and a FID, however, only the MS signal was used. Transfer line 175 temperature was $270{ }^{\circ} \mathrm{C}$ and the MS was run in SIM mode using a quantifier and qualifier ion for each 176 chemical. The method was operational down to typically $10 \mathrm{ng} / \mathrm{L}$ concentrations, depending on the 177 properties of the chemicals.

\section{$179 \quad 2.6$ Data analysis}

180 Aqueous standard solutions were used to determine the initial concentration level in the experiments. 181 For the rest of the experiment, biotic test systems were always referenced against abiotic test systems: 182 The measurement of each biotic test system was normalized by the mean of the three abiotic controls 
183 that were measured on the same GC-run. This yielded the relative response $\mathrm{R}$ for each biotic test system,

184 which was plotted as a function of incubation time and fitted to a first order degradation model with lag

185 phase (Equation 1) using no weighting and considering each replicate as an individual point in GraphPad

186 Prism 5.00.

187

(1) $\quad R=\left\{\begin{array}{cl}R_{0}, & \text { if } t<t_{\text {lag }} \\ R_{0} \cdot \exp \left(-k_{\text {system }} \cdot\left(t-t_{\text {lag }}\right)\right), & \text { if } t>t_{\text {lag }}\end{array}\right.$

$188 R_{0}$ is the relative response at time $0, t$ is the incubation time (days), $t_{\text {lag }}$ is the lag phase (days) and $k_{s y s t e m}$

189 is the first order degradation rate constant of the test system $\left(\right.$ days $\left.^{-1}\right)$.

190 Additional to the kinetic model, the $10 \%$ degradation time, $\mathrm{DT}_{10}$ and the degradation half-time, $\mathrm{DT}_{50}$, 191 which describe the time at which $10 \%$ and $50 \%$ of the test chemical was degraded in the test, 192 respectively, was found by equation (2) and (3).

193

194

(2) $D T_{10}=\frac{\ln (10 / 9)}{k_{\text {system }}}+t_{\text {lag }}$

(3) $D T_{50}=\frac{\ln (2)}{k_{\text {system }}}+t_{\text {lag }}$

195 As described in Birch et al. (2017) some of the chemicals distribute into the headspace. The first order 196 water phase degradation rate constant, $k_{\text {water, }}$ was calculated using the dimensionless Henry's laws 197 constant, $K_{H}{ }^{*}$, volume of water, $V_{w}$, and headspace, $V_{h}$, in the test system according to equation (4) (Birch 198 et al., 2017). The $K_{H}{ }^{*}$ and fraction in headspace are shown in Supporting Information (S3)

199

(4) $\quad k_{\text {water }}=k_{\text {system }} \cdot \frac{V_{w}+K_{H}^{*} V_{h}}{V_{w}}$ 


\section{3. Results and discussion}

\section{$202 \quad 3.1$ Surface water sample characteristics}

203 The reference compound, 1-octanol, was added to demonstrate the microbial activity of the inocula

204 (positive reference), and were degraded within one day in all five inocula.

205 Bacterial densities (heterotrophic plate counts) were higher in the streams than in the lakes, and the

206 urban lake and stream had higher densities than the rural lake and stream respectively (rural lake:

$2071.4 \cdot 10^{3} \mathrm{CFU} / \mathrm{mL}$, urban lake: $4.6 \cdot 10^{3} \mathrm{CFU} / \mathrm{mL}$, rural stream: $1.2 \cdot 10^{4}$, wastewater treatment plant (WWTP)

208 impacted stream: $1.5 \cdot 10^{4}$, urban stream: $8.0 \cdot 10^{4} \mathrm{CFU} / \mathrm{mL}$ ). The differences are probably caused by the

209 regular discharges of organic matter into urban streams compared to rural streams. The bacterial

210 densities are in the same range as the number of cells recommended in the standard OECD test guideline

211 'ready biodegradability' (OECD 301, 1992). The legends in Figures 1-3 are ordered from the highest to

212 lowest bacterial densities.

213 The five surface water samples had a pH between 7.7 and 8.0, organic carbon (NVOC) of $6-10 \mathrm{mg} / \mathrm{L}$ and

214 temperatures between $8-11^{\circ} \mathrm{C}$ (see Supporting Information S2). These parameters were thus quite

215 similar between test locations. Earlier studies have shown that uncharacterized dissolved organic carbon

216 in test systems leads to higher degradation rates and shortening of the acclimatization phase of

217 microorganisms (Kovarova-Kovar and Egli, 1998). However, because the amount of NVOC is similar in the

218 investigated surface waters, this parameter is not considered to be important for the differences in

219 biodegradation in this study.

220 The sample from the WWTP impacted stream showed slightly elevated concentrations of phosphate and

221 nitrate $\left(1.8 \mathrm{mg} / \mathrm{L} \mathrm{NO}^{3-}\right.$ and $\left.0.14 \mathrm{mg} / \mathrm{L} \mathrm{PO}_{4}{ }^{3-}\right)$ compared to the level in the other samples $(0.7-1.0 \mathrm{mg} / \mathrm{L}$ 
$222 \mathrm{NO}^{3-}$ and $0.01-0.06 \mathrm{mg} / \mathrm{LPO}_{4}{ }^{3-}$ ). These nutrient levels are sufficient for the total degradation of the test

223 chemicals, which were added in the $\mu \mathrm{g} / \mathrm{L}$ concentration level.

\section{$224 \quad 3.2$ Biodegradation}

225 Figure 1 shows the fit of the first order degradation model with lag phase to biodegradation data for $n$ -

226 decane, biphenyl and trans-decalin. $n$-Decane is an example of a chemical which was quickly degraded in

227 water from all test locations. Biphenyl was, similar to the other aromatic chemicals, quickly degraded 228 after a lag-phase. trans-Decalin is an example of a chemical with a slower degradation. Degradation 229 curves for the remaining chemicals are shown in Supporting Information (S4).

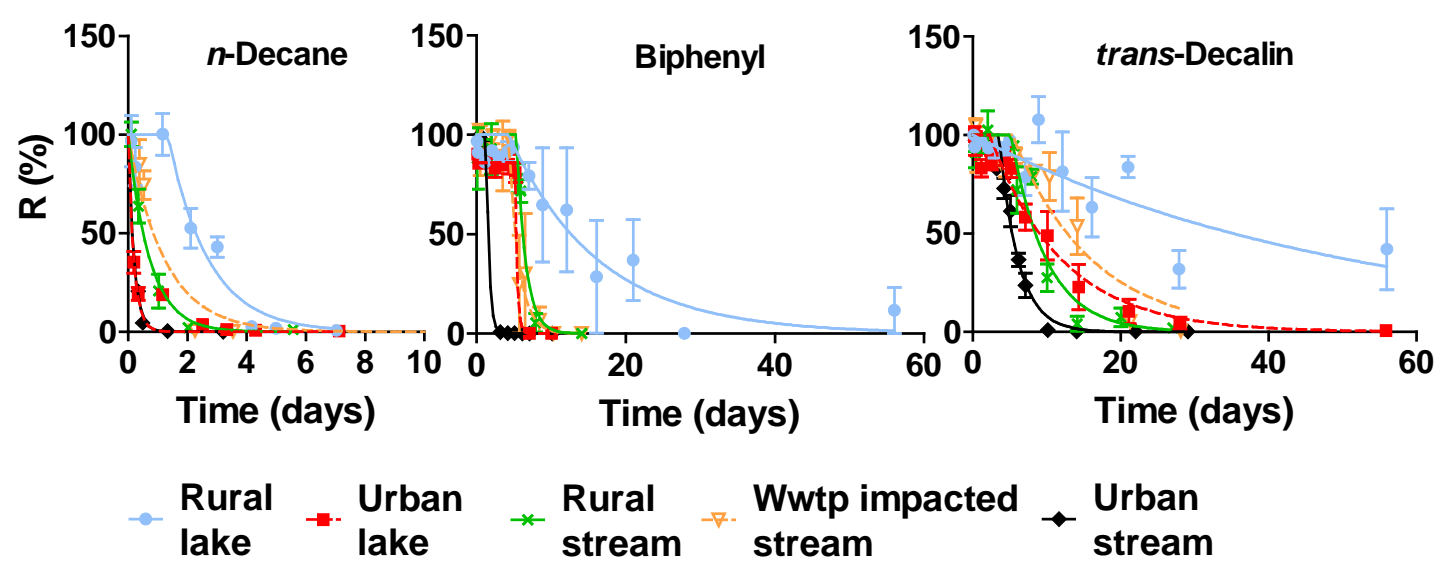

232

233 Figure 1: First order degradation curves for $n$-decane, biphenyl and trans-decalin in surface water from

234 three streams and two lakes. Legend order indicates increasing initial bacterial density. Error bars show

235 standard error of mean for the biotic test systems.

236 1,3,5-trimethylcyclohexane was the least degraded of the nine tested hydrocarbons. In the urban stream

237 sample degradation started after 8 days, and it was degraded according to $0^{\text {th }}$ order kinetics after day 18 
238 in the WWTP impacted stream. However, no degradation of 1,3,5-trimethylcyclohexane was seen in the 239 two lake samples, and degradation was only detected in two test systems in the rural stream sample

240 (one of three on day 14 and day 56). An explanation for the absence of biodegradation in some of the

241 samples could be that only rare specific degraders are able to degrade this hydrocarbon. The higher

242 microbial population in the urban stream and WWTP impacted stream would then increase the

243 probability of such degraders to be present in the test systems (Thouand et al., 2011). The fact that

244 1,3,5-trimethylbenzene was degraded in two test systems from the rural stream, which had the third

245 highest bacterial density, supports this explanation. The higher pre-exposure in the WWTP impacted

246 stream and the urban stream compared to the other samples, would further increase the probability of

247 specific degraders to be present in these samples. This structure is less susceptible to microbial

248 degradation than the other eight hydrocarbons tested in this experiment.

\section{$249 \quad 3.3$ Surface water origin effect on lag phase}

250 Lag phases were between $<1$ day and 8 days for eight of the nine tested hydrocarbons (see Figure 2). In

251 samples from all five locations very short lag phases (<2 days) were observed for $n$-decane and

252 bicyclohexyl, which have the lowest aqueous solubilities and were added at very low concentration

253 levels $(<1 \mu \mathrm{g} / \mathrm{L})$. This absence of lag phase shows that bacterial growth and adaptation was not needed

254 for initiating the biodegradation of these two compounds and that microbial populations capable of

255 degrading these two chemicals were widely present in the surface waters in numbers sufficient for

256 degradation at low concentrations levels. 
Streams

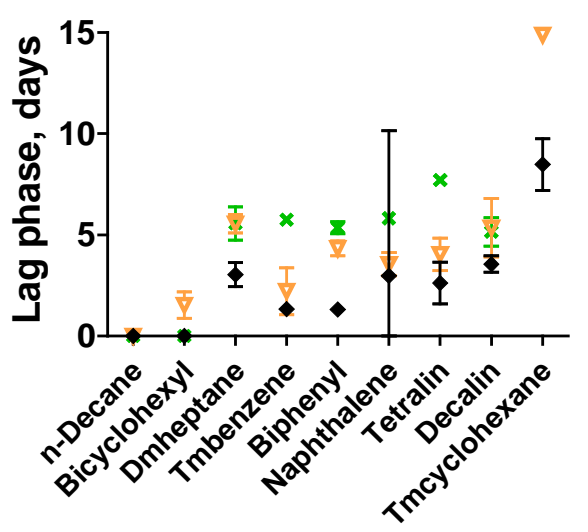

Lakes

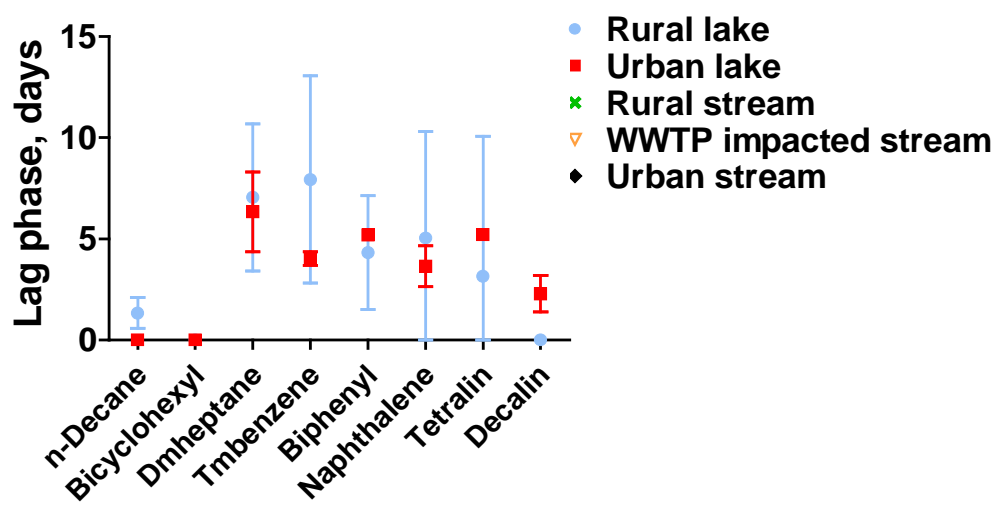
removed in the treatment plant before discharge, but bacteria from the treatment plant are discharged

Figure 2: Lag phases for the test chemicals in five surface water samples. 95\% confidence limits are shown except for trans-decalin in the rural lake and tetralin in the urban lake, for which confidence limits were wide.

Microbial activity and pre-exposure can affect lag phases. These two factors are, however, not independent because pre-exposure can lead to higher microbial activity and because of the likely correlation between pre-exposure and other anthropogenic pollution parameters such as eutrophication and input of microorganisms. The streams with higher urbanization were found to have higher bacterial densities. The microbial population in the urban stream is considered extensively pre-exposed to petroleum hydrocarbons because it receives stormwater runoff discharges (occasionally thin oil films are visible despite treatment in oil separators before discharge to the stream), and the WWTP impacted stream is considered medium pre-exposed to petroleum hydrocarbons since most hydrocarbons are with the effluent. Generally shorter lag-phases were seen in the urban stream than in the WWTP 
273 impacted stream and rural stream. This can be attributed to an effect of either the pre-exposure or the

274 higher bacterial density in the samples.

275 The only comparison in which pre-exposure can be separated from bacterial density is the rural stream, 276 which had a higher heterotrophic plate count than the more pre-exposed urban lake. The sample from

277 the urban lake showed shorter lag phases than the sample from the rural stream for 4 of the chemicals

278 and overlapping confidence limits for two chemicals even though the initial bacterial density was lower.

279 This finding indicates that higher pre-exposure of test locations shortened the biodegradation lag phase

280 compared to less pre-exposed locations, although only one pair of test locations could be used for this

281 comparison.

282 For most of the chemicals, confidence limits for the lag phase were much wider in the sample from the 283 rural lake than in the remaining samples. The reason for the wide confidence limits for the lag phase in 284 the rural lake is the lower degradation rates observed in the rural lake (see Figure 1), which makes it 285 difficult to determine the length of the lag phase with high accuracy and precision. An alternative 286 method to find lag-phases is to determine the $10 \%$ degradation time, $\mathrm{DT}_{10}$ (see equation 2 ), the time at 287 which the concentration is $90 \%$ of the initial concentration in the test systems. This method will primarily 288 affect determination of lag phases if the degradation is slow, and in this case primarily the rural lake. The $289 \mathrm{DT}_{10}$ for the rural lake was between 5-10 days for the degraded chemicals except the fast degrading $\mathrm{n}$ 290 decane and bicyclohexyl, and thus decalin did not show a shorter lag-phase in the rural lake than in 291 water from the other sites. 


\subsection{Comparison to BioHCwin predictions and sequence of degradation}

294 Degradation half-times (lag phase + one first order half-life) and BioHCwin half-life predictions for the test chemicals are shown in Figure 3 (and listed in Supporting Information S5). For four of the chemicals, the BioHCwin predicted half-lives were higher than the observed degradation half-times in all five surface waters. For four chemicals, the BioHCwin predictions were within the range of observed halftimes. For 1,3,5-trimethylcyclohexane, all the observed degradation half-times were longer than the BioHCwin prediction. The measured degradation half-times were thus shorter or within one order of magnitude of the BioHCwin predictions for 8 of 9 tested chemicals.

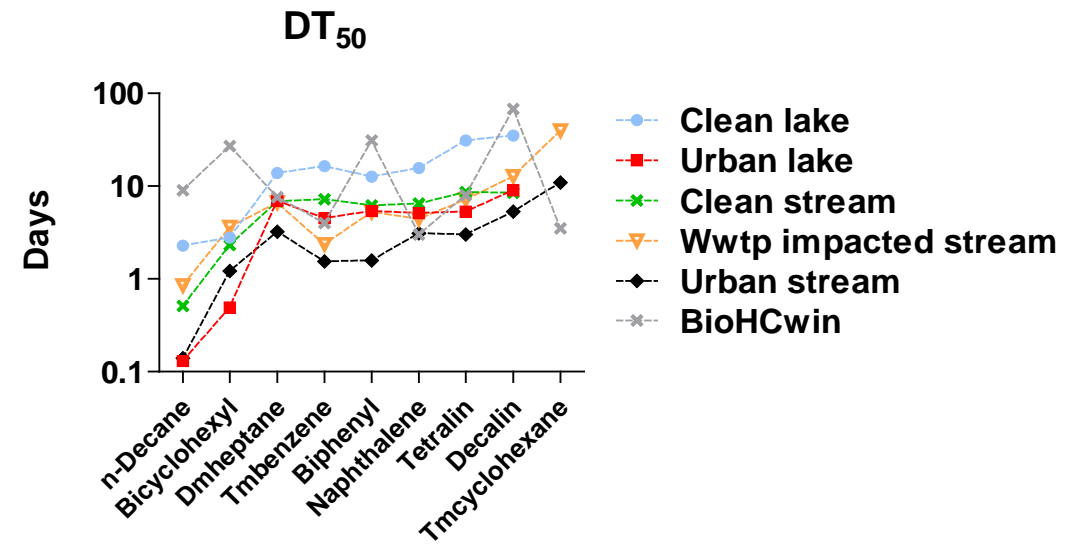

301

Figure 3: Degradation half-times (lag phase + one half-life) of test chemicals in surface water from five locations and BioHCwin predictions.

304 A preferential sequence of degradation of PAHs has earlier been observed using single strains or a mixed 305 bacterial culture (Leblond et al., 2001; Wammer and Peters, 2005). However, it has also been found that 306 in systems in which carbon sources are restricted and available as many different compounds at low 307 concentrations, heterotrophic organisms do not utilize only one carbon source, but assimilate many 308 compounds simultaneously (Kovarova-Kovar and Egli, 1998). The sequence of degradation of test 
chemicals was in this study largely conserved between the five surface water locations as illustrated in

310 Figure 3. $n$-decane and bicyclohexyl were degraded first, then 2,3-dimethylheptane and the four

311 aromatic test chemicals were degraded simultaneously, then trans-decalin and lastly 1,3,5-

312 trimethylcyclohexane (if degraded at all). Overall, the general sequence of degradability of

313 hydrocarbons, $n$-alkanes $>$ iso-alkanes $>$ low-molecular weight aromatics $>$ cyclic alkanes (Leahy and

314 Colwell, 1990), was therefore seen to describe the degradation in this experiment well. The exception

315 was the cyclic alkane bicyclohexyl, which was degraded before the low-molecular weight aromatics.

316 However, as will be discussed further below, the degradation rate constant of trans-decalin and 1,3,5-

317 trimethylcyclohexane is notably influenced by the test system dimensions, and these chemicals have a

318 shorter half-life in the water phase than in the test system (Birch et al., 2017). The BioHCwin predictions

319 did however not predict the same sequence of degradation.

320 The finding that the overall sequence of degradation was consistent in the samples from the different

321 locations opens the possibility for using benchmark chemicals in biodegradation testing. If a benchmark

322 chemical is included in a number of biodegradation studies it could then be used to relate or rank the

323 biodegradation capabilities of the inocula relative to each other. Furthermore, it could possibly be used

324 to estimate the degradation of a test chemical at one test location where only benchmark chemical

325 degradation was measured using data from another location where both the benchmark and test

326 chemical degradation were measured. In this way, kinetic data from different biodegradation

327 experiments could be compared even though the tests used inocula from different locations. This

328 approach would however be based upon the assumption that the factors that influence the degradation

329 of one chemical would change the degradation of another chemical in the same manner, and that there

330 would be no significant mixture effects on the degradation kinetics. Considering pre-exposure as such a

331 factor, the test chemical and benchmark chemical would have to have similar exposure routes for 
332 locations to be pre-exposed to the chemicals to the same degree. This is a more reasonable assumption

333 for chemicals which are emitted as mixtures (such as petroleum hydrocarbons) than for chemicals which

334 are emitted as single substances (e.g., pesticides). More work needs to be done, to reveal the potential

335 and limitations of the use of benchmark chemicals in biodegradation testing of hydrocarbons.

\subsection{Surface water origin effect on first order rate constants}

337 Test system and water phase first order degradation rate constants for the five surface waters are shown 338 in Figure 4.

Figure 4: Test system (left) and water phase (right) first order degradation rate constants for nine test

342 chemicals in five surface water samples. Water phase first order rate constants $>10 \mathrm{~d}^{-1}(5 n$-decane and

3432 dmheptane rate constants) were assigned a value of $10 \mathrm{~d}^{-1}$ in this figure. Error bars for test system rate

344 constants show $95 \%$ confidence limits except some rate constants above 1 , where large error bars were

345 omitted from the graph for visibility reasons. 
346 Contrary to our expectations, the biodegradation rate constants were affected to the same extent as the

347 lag phases by the differences in the urbanization of the sampling locations. The rate constants found in

348 samples from four of the test locations spanned approximately one order of magnitude, while lower rate

349 constants were found for the rural lake sample. Generally, the rate constants were highest in the urban

350 stream samples and lowest in water from the rural lake. For five of the chemicals the degradation rate

351 constants were higher in the urban lake sample, which had a lower initial bacterial density, than in the

352 rural stream sample, for two chemicals confidence limits overlapped, and for one chemical the rate was

353 higher in the rural stream sample.

354 When the test system rate constants were corrected for partitioning to headspace in order to determine

355 the water phase rate constants (Figure 3 right), the three first ( $n$-decane, bicyclohexyl and 2,3-

356 dimethylheptane) and two last chemicals (trans-decalin and 1,3,5-trimentylcyclohexane) on the $\mathrm{x}$-axis of

357 Figure 4 were mainly affected. This correction revealed that the main reason for a slower degradation of

358 trans-decalin was the headspace partitioning. The water phase rate constants for all tested chemicals in

359 the sample from the urban stream were above $1 \mathrm{~d}^{-1}$.

360 The difference in biodegradation rates found here shows that choice of inoculum location can be an

361 important consideration for biodegradation testing and can influence biodegradation kinetics. The

362 results show that a rural location without surface water runoff discharges can reveal conservative

363 biodegradation rates. However since these types of locations are not representative of most surface

364 waters, other locations can be more appropriate as input to aquatic exposure and fate models.

365 Independent of the type of location, this study can be used as input to quantify the uncertainty

366 associated with biodegradation kinetic data employed in fate and exposure models. 


\subsection{Extrapolation from test to environment}

368 Simulation biodegradation testing should ideally be conducted at environmentally realistic conditions in 369 order to obtain data which can be extrapolated to the environment. The focus and emphasis in the 370 present study was to improve environmental realism by testing of (1) composed mixtures rather than

371 single compounds, (2) at environmentally relevant low concentrations ( $\mathrm{ng} / \mathrm{L}-\mu \mathrm{g} / \mathrm{L}$ ) and (3) by

372 populations of native microorganisms from the different locations. Other factors and aspects were not

373 (yet) environmentally realistic: The tests were conducted at a temperature of $20^{\circ} \mathrm{C}$, which is higher than

374 at the sites from where the samples were taken and may lead to an underestimation of lag phases and

375 half-lives. The tests were also conducted in closed systems of $15 \mathrm{~mL}$, which implies a rather limited

376 population of microorganisms and an even more limited population of metabolic potent

377 microorganisms, which can lead to an overestimation of lag phases and half-lives. The latter is

378 particularly critical for surface waters with limited pre-exposure and low bacterial density, where the 379 presence of a sufficient amount of specific degraders may not be ensured in all test systems. This might 380 be part of the explanation for the markedly longer lag-phases and lower degradation rates for several 381 compounds in inoculum from the rural lake.

\section{4. Conclusions}

383 Measurements of the degradation of nine petroleum hydrocarbons in water from five diverse sampling 384 locations, showed biodegradation rate constants ranging a factor 10 for each chemical in water from 385 four of the five locations. Lag phases were comparable but generally slightly shorter in tests with inocula 386 from urban locations compared to rural locations. The first order degradation rate constants were also 387 lower in water from locations with low initial bacterial density and low urbanization. Although 388 biodegradation kinetics were influenced by differences in the level of urbanization of inoculum locations, 
the sequence of degradation was quite consistent among the five locations. The experiments thus show

390 the importance of the choice of sampling location for biodegradation tests, and open the possibility of

391 using benchmark chemicals in biodegradation testing of hydrocarbons.

392 The study showed the added value of combining partitioning based methods (passive dosing and HS-

393 SPME) with GC-MS analysis for testing biodegradation of mixtures of hydrophobic chemicals with low

394 water solubility to produce biodegradation kinetic data of high technical quality and at environmentally

395 relevant concentrations.

\section{Acknowledgements}

397 This work was supported by Concawe. The authors thank Hanne Bøggild for technical assistance in the

398 laboratory and Eleni Vaiopoulou and the Concawe Ecology Group for comments on the draft manuscript.

\section{References}

400

401

402

403

404

405

406

407

408
Abbasian, F., Lockington, R., Mallavarapu, M., Naidu, R., 2015. A Comprehensive Review of Aliphatic Hydrocarbon Biodegradation by Bacteria. Appl. Biochem. Biotechnol. 176, 670-699. doi:10.1007/s12010-015-1603-5

Bauer, J.E., Capone, D.G., 1988. Effects of Co-Occurring Aromatic Hydrocarbons on Degradation of Individual Polycyclic Aromatic Hydrocarbons in Marine Sediment Slurries. Appl. Environ. Microbiol. $54,1649-1655$.

Birch, H., Andersen, H.R., Comber, M., Mayer, P., 2017. Biodegradation testing of chemicals with high Henry's constants - Separating mass and effective concentration reveals higher rate constants. Chemosphere 174, 716-721. doi:10.1016/j.chemosphere.2017.02.003 
Birch, H., Mayer, P., Lützhøft, H.C.H., Mikkelsen, P.S., 2012. Partitioning of fluoranthene between free and bound forms in stormwater runoff and other urban discharges using passive dosing. Water Res. 46, 6002-6012. doi:10.1016/j.watres.2012.08.021

Caparello, D.M., Larock, P. a, 1975. A radioisotope assay for the quantification of hydrocarbon biodegradation potential in environmental samples. Microb. Ecol. 2, 28-42. doi:10.1007/BF02010379

Comber, M.I.H., den Haan, K.H., Djemel, N., Eadsforth, C.V., King, D., León Paumen, M., Parkerton, T., Dmytrasz, B., 2012. Primary Biodegradation of Petroleum Hydrocarbons in Seawater. Concawe, Brussels. doi:ISBN 978-2-87567-012-0

Cooney, J.J., Silver, S.A., Beck, E.A., 1985. Factors Influencing Hydrocarbon Degradation in Three Freshwater Lakes. Microb. Ecol. 11, 127-137.

European Parliament, 2000. Directive 2000/60/EC of the European Parliament and of the Council - of October 2000 - establishing a framework for Community action in the field of water policy. Off. J. Eur. Communities.

Göbel, P., Dierkes, C., Coldewey, W.G., 2007. Storm water runoff concentration matrix for urban areas. J. Contam. Hydrol. 91, 26-42. doi:10.1016/j.jconhyd.2006.08.008

Hamamura, N., Ward, D.M., Inskeep, W.P., 2013. Effects of petroleum mixture types on soil bacterial population dynamics associated with the biodegradation of hydrocarbons in soil environments. FEMS Microbiol. Ecol. 85, 168-178. doi:10.1111/1574-6941.12108

Hazen, T.C., Prince, R.C., Mahmoudi, N., 2016. Marine Oil Biodegradation. Environ. Sci. Technol. 50, 2121-2129. doi:10.1021/acs.est.5b03333 
430 Head, I.M., Jones, D.M., Röling, W.F.M., 2006. Marine microorganisms make a meal of oil. Nat. Rev. Microbiol. 4, 173-182. doi:10.1038/nrmicro1348

Howard, P., Meylan, W., Aronson, D., Stiteler, W., Tunkel, J., Comber, M., Parkerton, T.F., 2005. A new biodegradation prediction model specific to petroleum hydrocarbons. Environ. Toxicol. Chem. 24, 1847-1860. doi:10.1897/04-453R.1

Ingerslev, F., Toräng, L., Nyholm, N., 2000. Importance of the test volume on the lag phase in biodegradation studies. Environ. Toxicol. Chem. 19, 2443-2447. doi:10.1002/etc.5620191008

Kovarova-Kovar, K., Egli, T., 1998. Growth Kinetics of Suspended Microbial Cells: From Single-SubstrateControlled Growth to Mixed-Substrate Kinetics. Microbiol. Mol. Biol. Rev. 62, 646-666.

Kowalczyk, A., Martin, T.J., Price, O.R., Snape, J.R., van Egmond, R.A., Finnegan, C.J., Schäfer, H., Davenport, R.J., Bending, G.D., 2015. Refinement of biodegradation tests methodologies and the

Leahy, J.G., Colwell, R.R., 1990. Microbial degradation of hydrocarbons in the environment. Microbiol. proposed utility of new microbial ecology techniques. Ecotoxicol. Environ. Saf. 111, 9-22. doi:10.1016/j.ecoenv.2014.09.021

Kristensen, M., Johnsen, A.R., Christensen, J.H., 2015. Marine biodegradation of crude oil in temperate and Arctic water samples. J. Hazard. Mater. 300, 75-83. doi:10.1016/j.jhazmat.2015.06.046 
450 Marchal, R., Penet, S., Solano-Serena, F., Vandecasteele, J.P., 2003. Gasoline and Diesel Oil

451 Biodegradation. Oil Gas Sci. Technol. 58, 441-448. doi:10.2516/ogst:2003027

452 OECD 301, 1992. OECD Guideline for Testing of Chemicals. Ready Biodegradability.

453 doi:10.1787/9789264070349-en

454 OECD 303, 2001. OECD Guidelines for the Testing of Chemicals. Simulation Test - Aerobic Sewage

$455 \quad$ Treatment. doi:10.1787/9789264067394-eng

456 OECD 306, 1992. OECD Guidelines for the Testing of Chemicals. Biodegradability in Seawater.

457 doi:10.1787/9789264070486-en

458

OECD 309, 2004. OECD Guideline for the testing of Chemicals. Aerobic Mineralisation in Surface Water$459 \quad$ Simulation Biodegradation Test. doi:10.1787/9789264070547-en

460 Powell, S.M., Harvey, P.M., Stark, J.S., Snape, I., Riddle, M.J., 2007. Biodegradation of petroleum 461 products in experimental plots in Antarctic marine sediments is location dependent. Mar. Pollut.

$462 \quad$ Bull. 54, 434-440. doi:10.1016/j.marpolbul.2006.11.018

463 Prince, R.C., Butler, J.D., Redman, A.D., 2017. The rate of crude oil biodegradation in the sea. Environ. Sci.

$464 \quad$ Technol. 51, 1278-1284. doi:10.1021/acs.est.6b03207

465 Prosser, C.M., Redman, A.D., Prince, R.C., Paumen, M.L., Letinski, D.J., Butler, J.D., 2016. Evaluating

466 persistence of petroleum hydrocarbons in aerobic aqueous media. Chemosphere 155, 542-549.

467 doi:10.1016/j.chemosphere.2016.04.089

468 Rücker, C., Kümmerer, K., 2012. Modeling and predicting aquatic aerobic biodegradation - a review from 469 a user's perspective. Green Chem. 14, 875. doi:10.1039/c2gc16267a 
470 Smith, K.E.C., Dom, N., Blust, R., Mayer, P., 2010. Controlling and maintaining exposure of hydrophobic 471 organic compounds in aquatic toxicity tests by passive dosing. Aquat. Toxicol. 98, 15-24.

472 doi:10.1016/j.aquatox.2010.01.007

473 Smith, K.E.C., Rein, A., Trapp, S., Mayer, P., Karlson, U.G., 2012. Dynamic passive dosing for studying the 474 biotransformation of hydrophobic organic chemicals: Microbial degradation as an example.

$475 \quad$ Environ. Sci. Technol. 46, 4852-4860. doi:10.1021/es204050u

476 The Danish Nature Agency, 2011a. Vandplan 2009-2015. Isefjord og Roskilde Fjord. Hovedvandopland 477 2.2, Vanddistrikt Sjælland (in Danish) (River basin management plan 2009-2015).

478 The Danish Nature Agency, 2011b. Vandplan 2009-2015. Øresund. Hovedvandopland 2.3, Vanddistrikt 479 Sjælland (in Danish) (River basin management plan 2009-2015).

480 Thouand, G., Durand, M.J., Maul, A., Gancet, C., Blok, H., 2011. New concepts in the evaluation of 481 biodegradation/persistence of chemical substances using a microbial inoculum. Front. Microbiol. 2,

Toräng, L., Nyholm, N., 2005. Biodegradation rates in adapted surface water can be assessed following a preadaptation period with semi-continuous operation. Chemosphere 61, 1-10.

Van Hamme, J.D., Singh, A., Ward, O.P., 2003. Recent Advances in Petroleum Microbiology. Microbiol. Mol. Biol. Rev. 67, 503-549. doi:10.1128/MMBR.67.4.503 based study. Environ. Sci. Technol. 39, 2571-2578. doi:10.1021/es048939y 
490 